\title{
Front Matter: Volume 9806
}

, "Front Matter: Volume 9806," Proc. SPIE 9806, Smart Materials and Nondestructive Evaluation for Energy Systems 2016, 980601 (30 June 2016); doi: $10.1117 / 12.2229283$

Event: SPIE Smart Structures and Materials + Nondestructive Evaluation and Health Monitoring, 2016, Las Vegas, Nevada, United States 


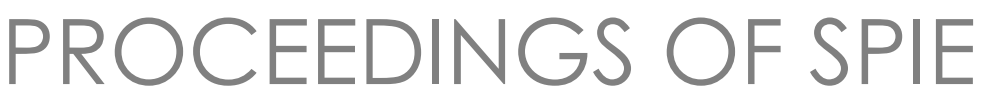

\title{
Smart Materials and Nondestructive Evaluation for Energy Systems 2016
}

\author{
Norbert G. Meyendorf \\ Theodoros E. Matikas \\ Kara J. Peters \\ Editors
}

21-23 March 2016

Las Vegas, Nevada, United States

Sponsored by

SPIE

Co-sponsored by

Polytec, Inc. (United States) OZ Optics, Ltd. (United States) - APS Dynamics, Inc. (United States) - The ElectroForce Systems Group of TA Electroforce Corporation

(United States) The Institute of Physics (United Kingdom) • American Elements (United States)

Cooperating Organizations

Intelligent Materials Forum (Japan)

Jet Propulsion Laboratory (United States)

National Science Foundation (United States)

Published by

SPIE

Volume 9806 
The papers in this volume were part of the technical conference cited on the cover and title page. Papers were selected and subject to review by the editors and conference program committee. Some conference presentations may not be available for publication. Additional papers and presentation recordings may be available online in the SPIE Digital Library at SPIEDigitallibrary.org.

The papers reflect the work and thoughts of the authors and are published herein as submitted. The publisher is not responsible for the validity of the information or for any outcomes resulting from reliance thereon.

Please use the following format to cite material from these proceedings:

Author(s), "Title of Paper," in Smart Materials and Nondestructive Evaluation for Energy Systems 2016, edited by Norbert G. Meyendorf, Theodoros E. Matikas, Kara J. Peters, Proceedings of SPIE Vol. 9806 (SPIE, Bellingham, WA, 2016) Six-digit Article CID Number.

ISSN: 0277-786X

ISSN: 1996-756X (electronic)

ISBN: 9781510600478

Published by

SPIE

P.O. Box 10, Bellingham, Washington 98227-0010 USA

Telephone +1 3606763290 (Pacific Time) · Fax +1 3606471445

SPIE.org

Copyright (C) 2016, Society of Photo-Optical Instrumentation Engineers.

Copying of material in this book for internal or personal use, or for the internal or personal use of specific clients, beyond the fair use provisions granted by the U.S. Copyright Law is authorized by SPIE subject to payment of copying fees. The Transactional Reporting Service base fee for this volume is $\$ 18.00$ per article (or portion thereof), which should be paid directly to the Copyright Clearance Center (CCC), 222 Rosewood Drive, Danvers, MA 01923. Payment may also be made electronically through CCC Online at copyright.com. Other copying for republication, resale, advertising or promotion, or any form of systematic or multiple reproduction of any material in this book is prohibited except with permission in writing from the publisher. The CCC fee code is 0277-786X/16/\$18.00.

Printed in the United States of America.

Publication of record for individual papers is online in the SPIE Digital Library.

\section{SPIE. DIGITAL}

Paper Numbering: Proceedings of SPIE follow an e-First publication model. A unique citation identifier (CID) number is assigned to each article at the time of publication. Utilization of CIDs allows articles to be fully citable as soon as they are published online, and connects the same identifier to all online and print versions of the publication. SPIE uses a six-digit CID article numbering system structured as follows:

- The first four digits correspond to the SPIE volume number.

- The last two digits indicate publication order within the volume using a Base 36 numbering system employing both numerals and letters. These two-number sets start with $00,01,02,03,04$, $05,06,07,08,09,0 A, 0 B \ldots$ OZ, followed by 10-1Z, 20-2Z, etc. The CID Number appears on each page of the manuscript. 


\title{
Contents
}

\author{
vii Authors \\ ix Conference Committee
}

\section{SESSION 1 FUEL CELLS AND ENERGY STORAGE}

980602 Nondestructive cell evaluation techniques in SOFC stack manufacturing (Keynote Paper) [9806-1]

980604 Investigating effectiveness of activated carbons of natural sources on various supercapacitors [9806-48]

\section{SESSION 2 SHM}

980605 Effects of temperature variations on guided waves propagating in composite structures [9806-4]

980606 Smart patch integration development of compression connector structural health monitoring in overhead transmission lines [9806-5]

980608 Optimization of monitoring and inspections in the life-cycle of wind turbines [9806-7]

980609 Disturbance observer based pitch control of wind turbines for disturbance rejection [9806-8]

\section{SESSION 3 ENERGY HARVESTING I}

9806 OA Energy harvesting from dancing: for broadening in participation in STEM fields [9806-9]

9806 OB Magnetoelastic beam with extended polymer for low frequency vibration energy harvesting [9806-11]

9806 OC Multiple piezo-patch energy harvesters integrated to a thin plate with AC-DC conversion: analytical modeling and numerical validation [9806-12]

9806 OE U-shape magnetostrictive vibration based power generator for universal use [9806-10]

\section{SESSION 4 KEYNOTE LECTURE}

9806 OF Highlights and challenges in nondestructive evaluation for metallic and composite structures (Keynote Paper) [9806-15] 
9806 OG Development of novel general equation for multistage epicyclic gearset with corrected teeth: non-constrained approach [9806-16]

9806 Ol Terahertz ISAR and x-ray imaging of wind turbine blade structures [9806-18]

9806 0J Neuro-fuzzy computing for vibration-based damage localization and severity estimation in an experimental wind turbine blade with superimposed operational effects [9806-19]

\section{SESSION 6 MATERIALS PROCESSING AND CHARACTERIZATION I}

$9806 \mathrm{OL} \quad$ Artificial feel system using magneto-rheological fluid on aircraft control stick [9806-21]

9806 OM A novel methodology for self-healing at the nanoscale in CNT/epoxy composites [9806-22]

9806 ON Ensuring near-optimum homogeneity and densification levels in nano-reinforced ceramics [9806-23]

\section{SESSION 7 PROPULSION}

$98060 Q \quad$ Performance of PZT stacks under high-field electric cycling at various temperatures in heavy-duty diesel engine fuel injectors [9806-26]

\section{SESSION 8 NUCLEAR ENERGY}

9806 OU Develop an piezoelectric sensing based on SHM system for nuclear dry storage system [9806-30]

\section{SESSION 9 MATERIALS PROCESSING AND CHARACTERIZATION II}

9806 OV NDE applications in microelectronic industries [9806-31]

\section{SESSION 10 ENERGY HARVESTING II}

9806 0X Wide operation frequency band magnetostrictive vibration power generator using nonlinear spring constant by permanent magnet [9806-33]

9806 OY Fatigue study and improve reliability of cantilever type micro piezoelectric energy harvesters reinforced with flexible adhesive conductive tape [9806-34]

$98060 Z$ Parameter study and optimization for piezoelectric energy harvester for TPMS considering speed variation [9806-35] 
980610 Design and experimental evaluation of flextensional-cantilever based piezoelectric transducers for flow energy harvesting [9806-36]

980611 Comparative studies on different nanofiber photocatalysts for water splitting [9806-49] POSTER SESSION

980612 Energy harvesting under excitation of clamped-clamped beam [9806-37]

980613 A study on the multilayer m-type thermoelectric power generation module using the metal direct bonding technology [9806-38]

980615 Acoustic metamaterial bar with non-linear spring-mass cells [9806-40]

980616 The effect of corrosion on the fatigue life of aluminum alloys [9806-41]

980618 Acoustic emission of fire damaged fiber reinforced concrete [9806-43]

9806 1A Design of piezoelectric transformer for DC/DC converter with stochastic optimization method [9806-45]

9806 1B Development of an advanced, high-frequency GPR technique for the assessment of concrete structures: from modeling predictions to experimental results [9806-46] 
Proc. of SPIE Vol. $9806980601-6$

Downloaded From: https://www.spiedigitallibrary.org/conference-proceedings-of-spie on 25 Apr 2023 Terms of Use: https://www.spiedigitallibrary.org/terms-of-use 
Yanaseko, Teturo, 13

Younis, Mohammad, OB

Yu, Lingyu, OU

Yuan, Yuan, 09

Proc. of SPIE Vol. $9806980601-8$

Downloaded From: https://www.spiedigitallibrary.org/conference-proceedings-of-spie on 25 Apr 2023 Terms of Use: https://www.spiedigitallibrary.org/terms-of-use 


\title{
Conference Committee
}

\author{
Symposium Chairs
}

Jayanth N. Kudva, NextGen Aeronautics, Inc. (United States)

Theodoros E. Matikas, University of loannina (Greece)

Symposium Co-chairs

Tribikram Kundu, The University of Arizona (United States)

Gregory W. Reich, Air Force Research Laboratory (United States)

\section{Conference Chair}

Norbert G. Meyendorf, lowa State University of Science and

Technology (United States)

Conference Co-chairs

Theodoros E. Matikas, University of loannina (Greece)

Kara J. Peters, North Carolina State University (United States)

Conference Program Committee

Ali Abdul-Aziz, NASA Glenn Research Center (United States)

George Y. Baaklini, NASA Glenn Research Center (United States)

Leonard Bond, lowa State University (United States)

Michael Dalichow, Quality Network Inc. (United States)

Peter Heilmann, arxes-tolina GmbH (Germany)

Manfred Johannes, South African Institute for Non-Desctructive Testing (South Africa)

Michael Kroening, Pontifícia Universidade Católica do Rio de Janeiro (Brazil)

Jinhong Liu, China General Nuclear Power Corporation (China)

Alexander Michaelis, Fraunhofer IKTS (Germany)

Piotr Omenzetter, University of Aberdeen (United Kingdom)

Dong-Jin Yoon, Korea Research Institute of Standards and Science (Korea, Republic of) 
Session Chairs

1 Fuel Cells and Energy Storage

Alexander Michaelis, Fraunhofer-IKTS (Germany)

2 SHM

Kara J. Peters, North Carolina State University (United States)

3 Energy Harvesting I

Christian Wunderlich, Fraunhofer-IKTS CMD (Germany)

4 Keynote Lecture

Piotr Omenzetter, University of Aberdeen (United Kingdom)

5 Wind Energy

Norbert G. Meyendorf, Franhofer IKTS-MD (Germany), University of Dayton (United States)

6 Materials Processing and Characterization I

Wieslaw M. Ostachowicz, The Szewalski Institute of Fluid-Flow Machinery (Poland)

7 Propulsion

Kara J. Peters, North Carolina State University (United States)

8 Nuclear Energy

Kara J. Peters, North Carolina State University (United States)

9 Materials Processing and Characterization II

Norbert G. Meyendorf, Franhofer IKTS-MD (Germany), University of Dayton (United States)

Theodoros E. Matikas, University of loannina (Greece)

10 Energy Harvesting II

Norbert G. Meyendorf, Franhofer IKTS-MD (Germany), University of Dayton (United States)

Theodoros E. Matikas, University of loannina (Greece) 